\title{
あいち健康の森公園
}

\section{Aichi Health Village Park}

石川 眞澄*

Masumi ISHIKAWA

\section{はじめに}

我が国の平均寿命が 80 年を超え， 21 世紀には 4 人に 1 人が 65 歳以上になるといわれる状況の中で，豊かな人生 経験を持った人々が健康で意欲的に社会活動に参加し，若 い世代とともに行動し生活する理想的な长寿社会を築いて いく必要がある。

愛知県では，この高齢化社会への対応のシンボルとして 「あいち健康の森」という新しい総合拠点の構想を, 昭和 62 年に発表し，その実現を目指し努力を積み重ねたが， ようやく平成 9 年 10 月に一部開園を迎えることができた。

「あいち健康の森」は明るい活力に満ちた長寿社会を創 造していくための医療, 福祉, 保健, 生きがいなどに関し た各分野にわたる施設をまとめて配置し，各々の施設が相 互に連携することによって, 高度に機能が発揮されること を期待されて計画されたものである。

\section{1. あいち健康の森}

昭和 60 年に国立療養所中部病院が高齿化社会の到来に 向けて「老人医療総合センター」を設置する構想を発表し, つづいて愛知県医師会が「健康の森建設構想」を発表した。

これらを受けて, 愛知県は昭和 62 年 6 月「あいち健康 の森（仮称）基本構想」を発表し，場所は大府市と東浦町 にまたがる国立中部病院，大府養護学校，大府運動公園な どを含む約 100 ヘクタールを対象として検討を行っていく こととした。

昭和 63 年度には学識経験者による基本計画策定会議を 設け, 立地場所と広さ, 各施設のイメージ, 事業主体, 事 業方式などの検討が行われた。

この基本計画では, 約 100 ヘクタールの区域を研究ゾー ン, 運動ゾーン, 健康ゾーン, 生きがいゾーン, 福祉ゾー ンの 5 ゾーンに分け, 各種施設を配置していくことにして おり，研究ゾーンには国立療養所中部病院と国に設置を要 望中の長寿科学研究センターなど, 運動ゾーンは大府運動 公園の屋外施設を利用して他の施設との連携を四り，健康
ゾーンには健康開発センター, 健康科学教育館, 滞在型学 習施設及び中央管理センターを置き, 生きがいゾーンは, スポーツ，レジャー，文化などの大規模なウェルネスラン ドとして第三セクターによる展開を図る，福祉ゾーンは新 しい考え方に基づくコミュニティケアセンターなど高㱓化 社会に対応する地域ケアに関連する諸施設を設置すること などが方向付けられている。

な技, 平成元年 1 月には厚生省で長寿科学研究センター (平成 5 年の工事着手時に国立長寿医療センターと名称変 更）を「あいち健康の森」の計画区域に設置することが決 定され，計画の実現が加速されることとなった。

\section{2. あいち健康の森公園}

「あいち健康の森」の計画区域約 100 ヘクタールのうち

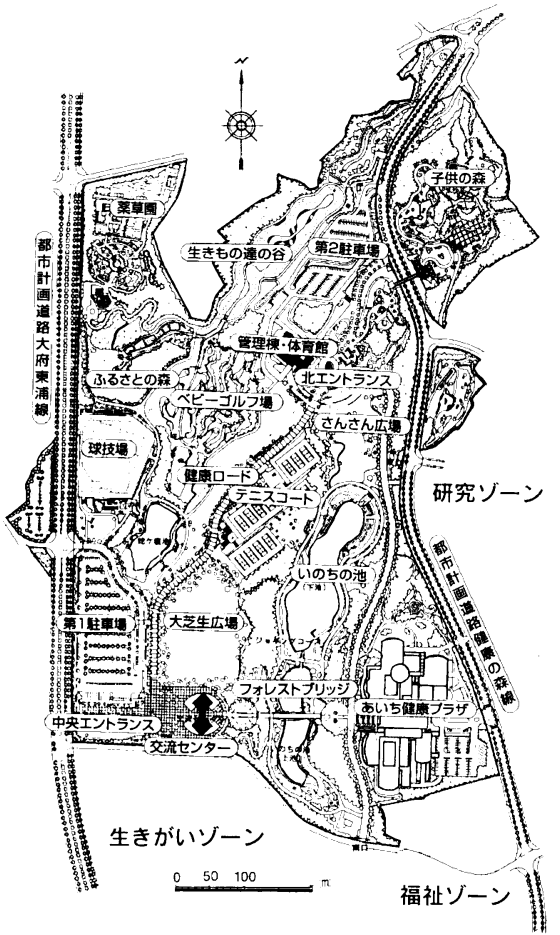

図－1 あいち健康の森公園計画平面図

*愛知県士木部公園緑地課 
約 2 分の 1 を健康ゾーン, 運動ゾーンとして, 県が実施し ていくこととして位置づけられたが，どのような手法で整 備を進めるかが, 全体を所管する衛生部の大きな課題であっ た。都市公園を担当する土木部との綿密な検討の結果, 健 康開発館等 4 施設は, 内容的にはほとんどが都市公園施設 として認められるものであるという判断が出来たため, 健 康ゾーン, 運動ゾーンの約 52 ヘクタールを都市計画公園 として都市計画决定を行い, 都市公園の中に衛生部の健康 増進, 長寿社会に対応する施設が設置許可を受けて設けら れるという形をとることになった。

その後, 平成 2 年度には建設省の都市公園補助事業のメ ニューの一つである地域活性化拠点公園（テーマパーク） 総合整備事業による調査費の補助を受けることができ, 公 園の基本構想, 基本計画を周辺地域の活性化, 地域産業の 振興の方針とと屯に策定し，事業のスタートを切ることが できた。

「あいち健康の森公園」は, 健康の森全体の中でも特に 一般の人々が自由に利用できる中心的な位置にあるため, 次のようなことを重要な役割とすることとした。

(1)誰むが参加できる屋内外を活用した健康スポーツ，生活 文化活動の体験実践の場

(2)水辺を中心とした森空間での自然とのふれあい, 自然へ の理解を深めることにより，「共生」を体感できる場

(3)心身をリフレッシュさせる「森」空間での活動を通した 交流の場, ふれあいの場

(4)実践的な活動を通して「新時代の健康」というテーマへ の研究, 開発, 学習の場

(5)隣接するゾーンからの活動発展の場

(6)健康の森に関する総合的な情報, サービスの提供の場

基本計画ではこれらを念頭に置き, 公園の施設内容, 配 置, 機能の検討が行われた。

その結果, 交流センター, 瞑想の森, ふるさとの森, 生 きもの達の谷, いのちの池, 薬草園などの新設と運動広場, 野外活動館, 子供の森, 大芝生広場などを既存施設の改築 で配置することになった。

\section{3. あいち健康の森公園の開園と今後の課題}

「あいち健康の森公園」は, 県教育委員会で所管の大府 運動公園を土木部に移管を受けて, 条例上は平成 6 年 4 月 1 日から開園した。

しかし本当の開園といえるのは改修施設，新規施設の一 部完成と「あいち健康プラザ（健康開発館等 4 施設）」の 開館の平成 9 年 10 月 28 日で, このときに公園としては駐 車場, 中央エントランス, 交流センター, いのちの池, フォ レストブリッジ, 大芝生広場の 16.8 ヘクタールを追加 供用し, 従来から供用していた区域（テニスコート, ベビー
ゴルフ, 北エントランス周辺，子供の森）を加えると 41.3 ヘクタールを供用することとなった。

その後平成 10 年 11 月に運動広場 (球技場), ふるさと の森が完成し，42.3ヘクタールの開園区域となった。

後に残る主要施設は, 生きむの達の谷, 子供の森の改築, 薬草園などであるが, 生きもの達の谷と子供の森は平成 1 2 年には完成の見込みになった。薬草園は江戸時代の尾張 藩の御薬園と管理役の細井長七郎の役宅を復元したものと 管理棟，温室などを建設する計画で，総事業費む十数億円 を要することから県の財政事情により本格的着工が先送り となっており, 完成, 開園は 13 年度末の予定から数年遅 れる見込みである。

「あいち健康の森」としては二期計画に「生きがいゾー ン」「福祉ゾーン」を含め約 100 ヘクタールの計画になっ ているが，「生きがいゾーン」参画予定の民間企業も経済 状況の悪化から, 直ちにこの事業を推進することに消極的 となり，準備段階のまま保留となっている。

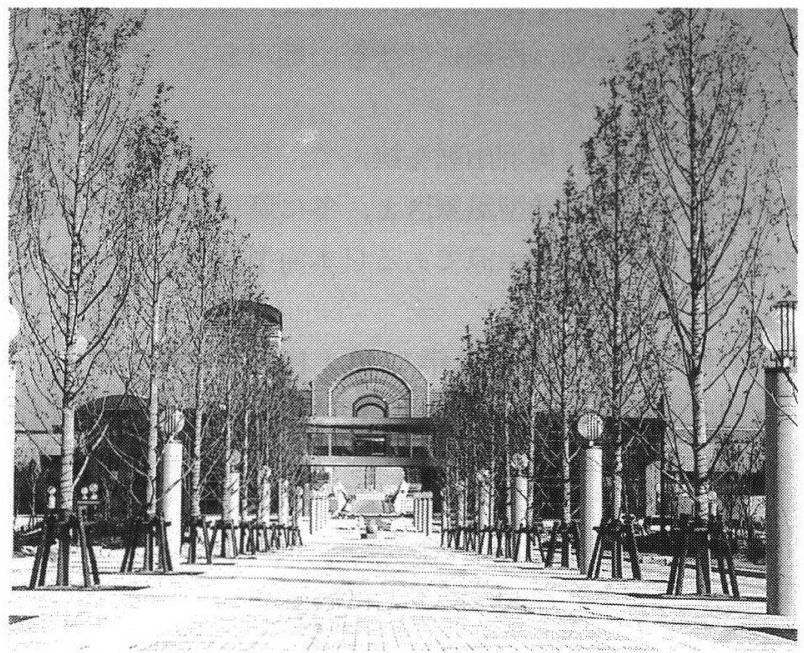

写真- 1 あいち健康の森公園

\section{おわりに}

愛知県の県営都市公園は, 従来は集中投資型ではなかっ たため計画から一部開園，全体完成までかなりの長期間を 要していたが「健康の森公園」は21 世紀に向けた県の主 要プロジェクトとして衛生部と協力して取り組み, さらに 地元大府市, 東浦町の絶大な支援もあったため比較的短期 間で部分開園，全体完成の見込みがたつようになった。

愛知県では，このように都市公園と他部局の所管する施 設と一体的に考え, 協力して公園づくりを行っていくこと がほとんど無かったが, 今後, 都市公園の持つ効果, 機能 を最大限に発揮させるため, また住民とって使いやすい, 楽しく活用できる公園を作るための手法として積極的に取 り組んでいく必要があると考えている。 